\title{
Identifikasi Bioaktif Golongan Flavonoid Tanaman Anting-Anting (Acalypha indica L.)
}

\author{
${ }^{1}$ Arief Pambudi, ${ }^{2}$ Syaefudin, ${ }^{1}$ Nita Noriko, ${ }^{1}$ Risa Swandari, ${ }^{1}$ Purwanty Rara Azura \\ ${ }^{1}$ Program Studi Biologi, Fakultas Sains dan Teknologi Universitas Al Azhar Indonesia, \\ Kompleks Mesjid Agung Al Azhar, Jl. Sisingamangaraja. Kebayoran Baru Jakarta Selatan 12110 \\ ${ }^{2}$ Program Studi Biokimia, Fakultas Matematika dan Ilmu Pengetahuan Alam, Institut Pertanian Bogor, \\ Kampus IPB Darmaga, Bogor 16680 \\ ${ }^{1}$ Penulis untuk Korespondensi, email: pambudi@uai.ac.id
}

\begin{abstract}
Abstrak - Indonesia merupakan negara dengan kekayaan alam yang melimpah. Namun, untuk jenis tumbuhan, baru sekitar $8 \%$ yang dimanfaatkan sebagai tanaman pangan, obat-obatan, sumber kayu, dan tanaman hias. Salah satu tanaman yang berpotensi sebagai tanaman obat adalah Acalypha indica. Penelitian sebelumnya menunjukkan bahwa ekstrak tanaman ini memiliki aktivitas antibakteri Salmonella. Namun profil senyawa metabolit apa saja yang terkandung masih belum banyak diteliti. Fraksinasi senyawa metabolit dilakukan dengan kromatografi kertas pada ekstrak etanol (akar, batang, dan daun) tanaman Acalypha menggunakan eluen BAW (Butanol: Asam asetat: Air = 4:1:5) dan asam asetat $15 \%$. Jumlah, letak, warna, dan nilai Rf bercak kemudian digunakan sebagai pedoman identifikasi dan menduga golongan flavonoid. Spektrofotometri serapan panjang gelombang maksimum dilakukan sebagai konfirmasi dugaan golongan flavonoid. Ketiga organ utama tanaman anting-anting (akar, batang, dan daun) memiliki distribusi kandungan senyawa yang berbeda-beda namun dengan jenis yang hampir sama. Golongan flavonoid yang berhasil teridentifikasi dari ketiga organ antara lain isoflavon, flavon, flavonol, flavanon, dihidroksiflavonol, khalkon, dan antosianidin. Organ daun memiliki keragaman kelas flavonoid lebih banyak dibanding akar dan batang.
\end{abstract}

Abstract - Indonesia is a megabiodiversity country, but only about $8 \%$ of its plant diversity are utilized as food, medicine, timber, and ornamental plants. One plant species that potential to be used as a medicinal plant is Acalypha indica. Previous research showed this plant extract has some antibacterial activiting against Salmonella. However, the profile of the metabolites contained in the plant is not studied yet. Fractination of the metabolites was done by using paper chromatography in ethanol extract (roots, stems, and leaves) of Acalypha plants using BAW (butanol: acetic acid: water $=4: 1: 5$ ) and 15\% acetic acid eluent. Number, location, color, and Rf values of spots were used for identification of flavonoids class. Maximum absorption wavelength performed using spectrophotometry assay to confirm the flavonoid class. The three major plant organs (roots, stems, and leaves) have different compounds distribution, but with almost same class. Class of flavonoids which were identified from the three organs are isoflavones, flavones, flavonols, flavanones, dihidroxyflavonols, chalcones, and anthocyanidins. Leaf has more diverse flavonoid class than roots and stems.

Keyword - Acalypha indica bioactive compound, chromatography, flavonoids.

\section{PENDAHULUAN}

$\mathrm{L}$ uas wilayah daratan Indonesia adalah sekitar $1,3 \%$ dari luas daratan dunia [1]. Namun sebanyak $17 \%$ dari tumbuhan dan hewan di dunia terdapat di Indonesia [2]. Setidaknya sekitar 38000 spesies tumbuh-tumbuhan terdapat di Indonesia dan 55\% diantaranya merupakan spesies endemik. Hal ini membuat Indonesia menduduki peringkat kelima dalam keragaman tumbuh-tumbuhan dunia
[3]. Tingginya keragaman tumbuh-tumbuhan Indonesia, menjadikan Indonesia sebagai negara dengan sumber berbagai bahan bioaktif potensial. Berbagai bahan bioaktif ini dapat dimanfaatkan terutama dalam bidang industri, kesehatan, dan farmasi.

Ironisnya, kekayaan alam yang melimpah ini belum sepenuhnya diteliti, digali, dan dimanfaatkan. Dari 38000 spesies tumbuhan Indonesia, baru sekitar 
2000 spesies $(5,3 \%)$ yang terdata dan dimanfaatkan sebagai tanaman obat [1], 350 spesies $(0,92 \%)$ digunakan sebagai sumber kayu, 477 spesies $(1,25 \%)$ merupakan palem-paleman yang berpotensi sebagai tanaman hias [3]. Sehingga praktis lebih dari $92 \%$ sisanya masih belum banyak diteliti dan dimanfaatkan.

Salah satu tanaman yang berpotensi sebagai tanaman obat adalah Acalypha indica. Tanaman herba ini secara tradisional sudah dimanfaatkan untuk pengobatan disentri, malnutrisi, mimisan, muntah darah, berak darah, kencing darah dan malaria. Namun penggunaannya sebagai tanaman obat masih terbatas pada pengobatan tradisional dalam bentuk air rebusan, belum sampai pada tanaman obat modern yang memang terbukti secara farmakologis karena adanya kandungan bioaktif tertentu.

Penelitian Acalypha sebenarnya mulai dilakukan di India sejak tahun 1979 [4], namun itu masih terbatas pada potensinya sebagai antifungi. Namun sepanjang kurun waktu yang lama, penelitian mengenai tanaman ini tidak banyak mengalami kemajuan. Mulai 2005, baru muncul beberapa penelitian lain terkait potensi lain dari Acalypha seperti aktivitas antimikroba [5],[6], anti asam urat [7], antidiabetes [8], sumber nutrisi [9], dan antioksidan [10].

Penelitian mengenai potensi ekstrak kasar Acalypha sebagai senyawa antibakteri Salmonella thypi telah dilakukan di FST UAI [11], namun belum pada jenis metabolit sekundernya. Penelitian lanjutan mengenai profil metabolit sekunder golongan flavonoid tanaman Acalypha secara umum dapat menjadi penelitian awal dalam pemanfaatan bioaktif potensial. Penelitian diarahkan pada jenis organ mana (akar, batang, dan daun) yang mengandung bioaktif paling beragam. Gambaran umum mengenai profil kandungan metabolit sekunder golongan flavonoid dapat menjadi pijakan dasar untuk menentukan kemudian mengisolasi senyawa potensial sebagai antimikroba, antioksidan, atau senyawa lain yang bermanfaat bagi kesehatan. Hingga pada akhirnya senyawa antimikroba dan antioksidan potensial hasil isolasi dari tanaman Acalypha dapat diarahkan sebagai pengawet alami. Selain itu, kandungan antioksidannya dapat menjadi suplemen tambahan yang dapat menjadi sumber fortifikasi pembuatan tepung ganyong berspirulina sebagai substitusi tepung terigu yang akan dikembangkan juga oleh FST UAI.

\section{TINJAUAN PUSTAKA}

\section{Botani tanaman Acalypha}

Acalypha indica merupakan tanaman yang tergolong dalam divisi Spermatophyta, kelas dikotil, dan famili Euphorbiaceae [12]. Tanaman ini merupakan tanaman herba tahunan, tegak dengan beberapa cabang tegak (Gambar 1). Batangnya bertrikoma, daunnya tunggal, bertangkai panjang, bentuk daun bundar telur hingga belah ketupat, tepi daun beringgit hingga bergerigi, tipis dan halus, duduk daun tersusun spiral. Bunganya merupakan bunga majemuk bulir, unisek, terletak pada ketiak daun dan ujung cabang, memiliki braktea. Bunga betina lebih pendek, tegak, dan jorong dibanding bunga jantan. Buahnya merupakan buah kapsul, kecil, dikelilingi braktea, bijinya oval, halus, berwarna coklat muda [13].

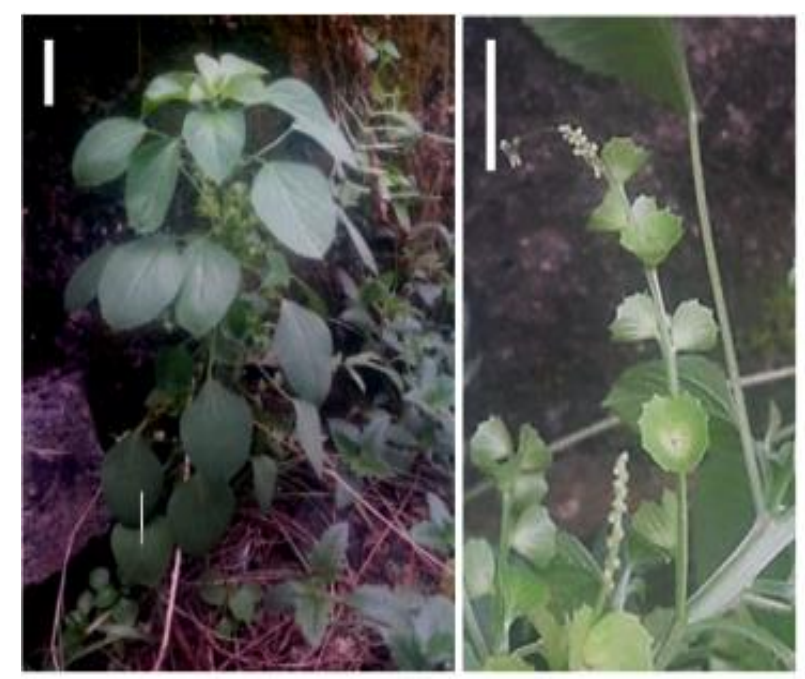

Gambar 1 Habitus dan bunga tanaman Acalypha indica. Bar putih menunjukkan skala $1 \mathrm{~cm}$.

Menurut data protabase, kandungan dalam jaringan kering Acalypha antara lain glikosida sianogenik, akalifin yang merupakan derivat dari 3sianopiridon, flavonoid berupa glikosida kaemferol, mauritianin, clitorin, nicotiflorin, biorobin, tanin, $\beta$ sitosterol, acalyphamide, aurantiamide, succinimide, dan flindersin. JSelain itu, terdapat kandungan lain, yaitu triacetonamine, noctacosanol, quebrachitol, dan asam hidrosianat [13].

Pemanfaatan Acalypha sebagai tanaman obat tradisional sudah banyak dilakukan. Air rebusan Acalypha dapat mengobati sakit gigi dan infeksi telinga, bubur daunnya dapat untuk mengobati luka bakar dan rematik [14]. Ekstrak tanaman Acalypha 
juga dapat berperan sebagai kontrasepsi alami [15], analgesik dan antiinflamasi [16], efek neuroterapi dan neuroprotektan [17], menurunkan glukosa darah [8], menurunkan asam urat [7]. Beberapa penelitian melaporkan bahwa ekstrak Acalypha dapat menghambat pertumbuhan beberapa bakteri patogen [5], [6], [18].

\section{Senyawa Bioaktif}

Senyawa bioakif umumnya dihasilkan melalui metabolisme sekunder. Berbeda dengan metabolit primer, metabolit sekunder lebih berperan dalam pertahanan dan peran ekologis tanaman dengan lingkungannya. Tiga kelompok besar senyawa metabolit sekunder pada tumbuhan antara lain terpenoid, alkaloid, dan senyawa fenol [19].

Flavonoid merupakan derivat dari senyawa fenol. Secara umum, flavonoid merupakan senyawa dengan 15 atom karbon yang tersusun dalam konfigurasi C6-C3-C6, yaitu dua cincin aromatik yang dihubungkan oleh tiga karbon yang dapat atau tidak dapat membentuk cincin ketiga (Gambar 2). Gugus hidroksil (-OH) hampir selalu terdapat dalam flavonoid, khususnya pada cincin B di posisi 3' dan 4', cincin A pada posisi 5 dan 7, atau cincin $\mathrm{C}$ pada posisi 3. Gugus hidroksil ini merupakan tempat menempelnya berbagai gula yang dapat meningkatkan kelarutan flavonoid dalam air. Sebagian besar flavonoid disimpan dalam vakuola tengah, walaupun disintesis di luar vakuola [20].

Berdasarkan strukturnya, [21] menggolongkan flavonoid dalam enam kelompok antara lain aglikon (flavonoid tanpa gula terikat), flavonoid-Cglikosida (flavonoid yang terikat gula pada inti benzena), flavonoid-O-glikosida (flavonoid yang terikat gula pada gugus hidroksilnya), biflavonoid (flavonoid biner), flavonoid sulfat (flavonoid yang berikatan dengan satu atau lebih gugus sulfat), dan aglikon yang bersifat optis aktif. Sedangkan menurut fungsi fisiologisnya [19] flavonoid dikelompokkan menjadi tiga, yaitu antosianin (flavonoid yang berperan sebagai pigmen warna), flavonol dan flavon (perlindungan terhadap radiasi UV berlebih dan sebagai sinyal biologis), dan isoflavon (flavonoid biner yang banyak berperan sebagai senyawa pertahanan). Walaupun terlihat beragam, namun golongan flavonoid disintesis oleh prekursor yang sama (fenilalanin, yang merupakan asam amino aromatik) melalui jalur biosintesis asam sikimat yang khas hanya terdapat pada tumbuhan [19].

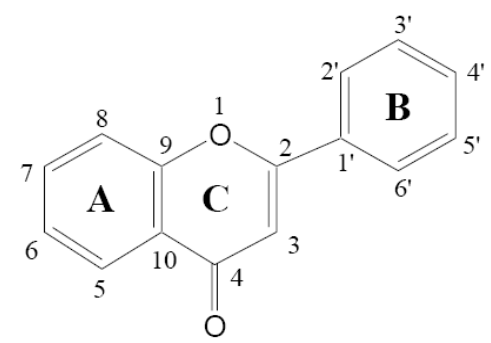

Gambar 2. Struktur umum flavonoid [20]

\section{Antimikroba dan Antioksidan}

Senyawa antimikroba merupakan kelompok senyawa yang memiliki aktivitas menghambat atau menghentikan pertumbuhan mikroorganisme [6]. Yang termasuk dalam senyawa antimikroba antara lain senyawa antibakteri, antifungi, antiprotozoa, dan antivirus. Berdasarkan toksisitasnya, senyawasenyawa antimikroba dapat digolongkan menjadi dua kelompok, senyawa yang bersifat menghambat dan senyawa yang bersifat menghentikan (membunuh). Pada konsentrasi yang tinggi, umumnya senyawa penghambat dapat berperan sebagai senyawa pembunuh. Sehingga hal penting dalam penggunaan senyawa antimikroba adalah sifat selektifitas terhadap mikroorganisme sasaran dan inang. Senyawa antimikroba yang baik adalah jika tidak memberikan efek penghambatan pada inang, namun memberi efek penghentian pada sasaran (selektif). Mode kerja dari senyawa antimikroba secara garis besar antara lain mengganggu permeabilitas membran melalui interaksi dengan protein membran dan dinding sel, interaksi dengan asam nukleat sehingga menghambat replikasi dan ekspresi gen mikroba, dan penghambatan pertumbuhan mikroba melalui interaksi enzimatik [22].

Senyawa antioksidan merupakan senyawa yang mampu menunda atau menghambat oksidasi lipid oleh radikal bebas [23]. Berdasarkan mekanisme kerjanya, antioksidan dibedakan menjadi antioksidan primer (antioksidan yang mampu menstabilkan rantai lipid radikal melalu reaksi penetralan) dan antioksidan sekunder (antioksidan yang menetralkan radikal bebas melalui pengikatan ion logam, penangkapan oksigen radikal, pemecahan hidrogen peroksida, deaktivasi singlet oksigen, dan penyerapan radiasi UV berlebih).

Flavonoid dapat berperan sebagai antioksidan karena flavonoid bertindak sebagai free radical scavengers dengan melepaskan atom hidrogen dari 
gugus hidroksilnya. Atom hidrogen yang dilepaskan mampu berikatan dengan radikal bebas, hingga bermuatan netral. Flavonoid yang kehilangan atom hidrogen kemudian mengalami resonansi dari gugus hidroksil yang menyebabkan energi aktivitasnya berkurang dan tetap stabil. Radikal bebas yang sudah distabilkan akan berhenti melakukan reaksi berantai sehingga mencegah terjadinya kerusakan lipid, protein, atau DNA [23].

Aktivitas antimikroba dan antioksidan dapat diterapkan dalam proses preservasi (pengawetan) suatu bahan. Jika senyawa antimikroba dan antioksidan berasal dari bahan alami, maka preservasi dapat dilakukan secara alami yang dapat mengurangi efek-efek negatif dalam preservasi menggunakan preservatif buatan. Hal terpenting dalam preservasi adalah menjaga agar bahan mampu disimpan dalam jangka waktu lama dengan mencegah pertumbuhan mikroba patogen dan mencegah perubahan sifat bahan selama penyimpanan karena aktivitas oksidasi. Kedua hal ini dapat diterapkan salah satunya dengan penambahan senyawa antimikroba dan antioksidan yang berasal dari bahan alami [24].

\section{Kromatografi}

Kromatografi adalah teknik pemisahan dan pemurnian komponen dari campurannya yang umum [25]. Teknik kromatografi merupakan teknik pemisahan suatu campuran yang berdasarkan kepada kesetimbangan fase, yaitu fase diam dan fase bergerak. Fase diam merupakan lapisan cairan pelarut (pengembang) yang teradsorpsi pada permukaan kertas, sedangkan fase bergerak merupakan bagian pelarut (pengembang, eluen) yang berfungsi menggerakkan komponen [26]. Teknik ini didasarkan pada perbedaan kecepatan migrasi senyawa saat diberi eluen tertentu. Secara umum, ada beberapa macam teknik kromatografi, yaitu kromatografi kertas (KK), kromatografi lapis tipis (KLT), kromatografi kolom, kromatografi gas, dan kromatografi kinerja tinggi (KKT).

Teknik kromatografi yang paling umum untuk analisis pendahuluan ekstrak tumbuhan untuk menguji adanya flavonoid adalah kromatografi kertas [21]. Namun analisis dengan KLT memiliki beberapa keunggulan dibandingkan dengan kromatografi kertas, diantaranya kesebangunan dari plat KLT, kecepatan saat proses migrasi, serta sensitivitasnya sehingga dengan sampel yang sedikit sudah mampu memberikan hasil yang baik [25].
Hasil yang diperoleh dari analisis menggunakan KK atau KLT adalah warna bercak dan nilai Rf untuk menduga jenis senyawa yang terkandung dalam suatu sampel bahan. Nilai Rf didefinisikan sebagai kecepatan suatu senyawa saat bermigrasi dalam proses kromatografi. Nilainya dapat ditentukan dengan membagi jarak yang ditempuh suatu senyawa (jarak titik awal ke suatu bercak) dengan jarak yang ditempuh oleh garis depan pengembang (jarak titik awal ke garis akhir). Nilai Rf suatu senyawa spesifik, sehingga dengan mengetahui nilai $\mathrm{Rf}$ dapat diketahui jenis senyawa yang terkandung dalam suatu sampel [23]. Selain warna bercak dan nilai Rf, sebagai konfirmasi dapat dilakukan pula pengukuran panjang gelombang serapan maksimum menggunakan spektrofotometer UV-Vis. Tiap senyawa memiliki serapan maksimum yang khas pada panjang gelombang tertentu.

\section{METODE PENELITIAN}

\section{Waktu dan Tempat}

Penelitian dilakukan pada bulan Maret - Agustus 2013 di laboratorium kimia Universitas Al Azhar Indonesia.

\section{Bahan dan Alat}

Bahan yang digunakan antara lain tanaman Acalypha indica, metanol, butanol, asam asetat, $\mathrm{HCl}$, akuades, kertas whatman no 1 , kertas whatman no 3, dan amoniak. Sedangkan alat yang digunakan antara lain oven, mortar porselen, blender kering, neraca analitik, sentrifuse, tabung ependorf, bejana kromatografi, lampu UV (300 $\mathrm{nm}$ ), pengering rambut, termometer, alat-alat gelas, hot-plate, magnetic stirer, dan pipet mikro.

\section{Cara Kerja}

Penyiapan simplisia dan ekstraksi. Tanaman Acalypha terlebih dahulu dibersihkan dari tanah, dipisahkan bagian akar, batang, dan daunnya lalu dibungkus terpisah dengan koran. Sampel basah tersebut kemudian dikeringkan menggunakan oven pada suhu $40^{\circ} \mathrm{C}$ selama $24-48$ jam hingga kering sepenuhnya. Setelah tanaman kering, masingmasing bagian tadi (akar, batang, dan daun) dihancurkan menggunakan mortar atau blender hingga berbentuk serbuk kering. Simplisia yang telah dihasilkan kemudian dimaserasi dengan etanol $70 \%$ panas 1:5 (b:v) selama 10 menit. Ekstrak yang dihasilkan kemudian disaring menggunakan kertas saring. 
Fraksinasi senyawa flavonoid. Fraksinasi dilakukan menggunakan teknik kromatografi kertas (KK) dua arah. Ekstrak hasil ekstraksi dicoba ditotolkan sebanyak 30, 40, dan $50 \mu \mathrm{l}$ pada kertas Whatman no 1 dan dikeringkan menggunakan pengering rambut. Setelah kering plat sampel kemudian dikembangkan dengan eluen yang sesuai untuk analisis flavonoid. Eluen yang digunakan antara lain BAA (Butanol: Asam asetat: Akuades = 4:1:5) dan Asam asetat 15\% sesuai yang diuraikan dalam [10].

Analisis dugaan kelompok flavonoid. Bercak pada kromatogram yang timbul diamati dengan menggunakan lampu UV (300 nm) sebelum dan setelah diberi uap amoniak. Warna bercak sebelum dan sesudah diuapkan dicocokkan dengan literatur [21]. Nilai Rf dihitung untuk penentuan dugaan jenis senyawa dengan membandingkan jarak bercak dengan jarak tempuh larutan eluen [27]. Sebagai konfirmasi tambahan, akan dilakukan juga pengujian serapan maksimum panjang gelombang menggunakan spektrofotometer.

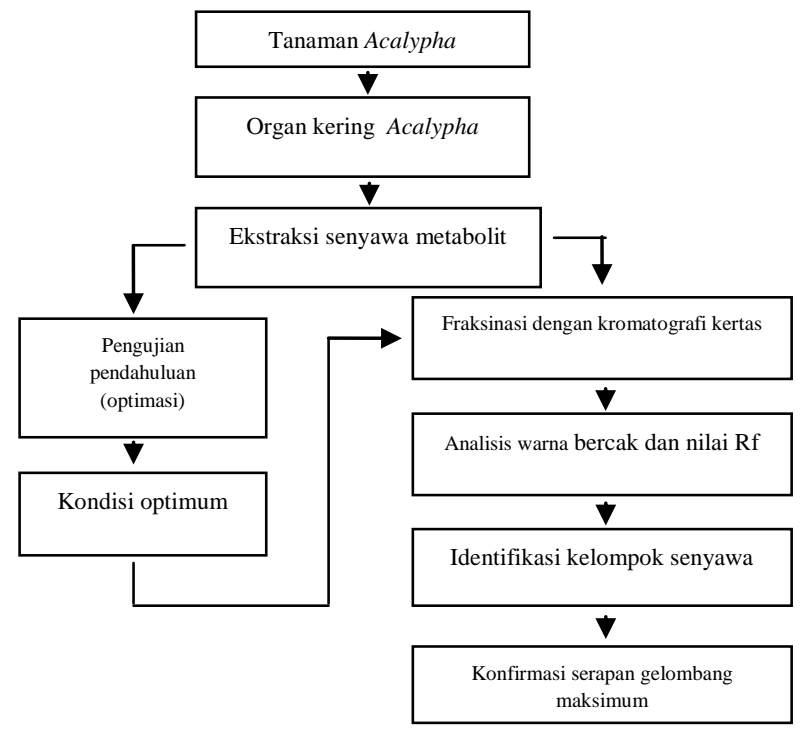

Gambar 3 Alur kerja penelitian yang dilakukan.

\section{HASIL DAN PEMBAHASAN}

\section{Persiapan Simplisia dan Optimasi Keadaan Kromatografi}

Simplisia diekstrak menggunakan etanol $70 \%$ yang dididihkan terlebih dahulu kemudian dilakukan penyaringan. Ekstrak etanol dari setiap organ tanaman yang kemudian digunakan dalam kromatografi.
Saat optimasi jumlah volume sampel digunakan kertas saring biasa dan kertas whatman no 3, tidak langsung dilakukan pada plat selulosa karena keterbatasan plat. Namun, plat selulosa ternyata tidak sesuai untuk matriks kromatografi senyawa golongan flavonoid. Saat digunakan plat selulosa sama sekali tidak ada bercak yang muncul. Sehingga untuk selanjutnya digunakan kromatografi kertas dengan kertas whatman no 1 dan no 3.

Dari hasil optimasi, volume $40 \mu \mathrm{l}$ merupakan volume sampel terbaik (tidak terlalu banyak dan tidak terlalu sedikit) untuk melihat pola bercak yang timbul. Setelah diperoleh volume optimum, dicobakan elusi kromatografi satu arah dengan kertas saring. Hasil kromatografi satu arah disajikan pada Gambar 4. Kromatografi satu arah menunjukkan ada bercak dengan pola dan warna yang berbeda antar tiap serbuk organ. Hal ini menunjukkan bahwa kertas saring dapat digunakan sebagai matriks dalam kromatografi senyawa golongan flavonoid. Untuk memastikan bercak yang muncul, dilakukan kromatografi dua arah dengan asam asetat $15 \%$.

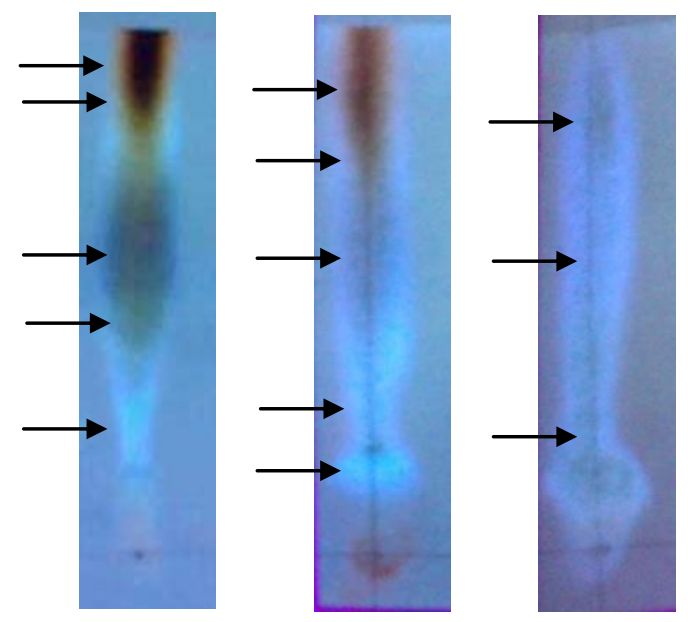

Gambar 4 Pola kromatogram satu arah menggunakan eluen BAW. Tanda panah menunjukkan senyawa yang berbeda untuk tiap organ.

\section{Kromatografi Kertas Dua Arah}

Kromatografi kertas dilakukan dua arah untuk memisahkan senyawa metabolit dengan kecepatan gerak (Rf) yang berdekatan sehingga diperoleh pemisahan terbaik. Kromatografi dua arah dilakukan pada tiga organ tanaman Acalypha. Hasil kromatografi dua arah berturut-turut untuk organ batang, akar, dan daun berturut-turut disajikan pada Gambar 5 dan Tabel 1. 

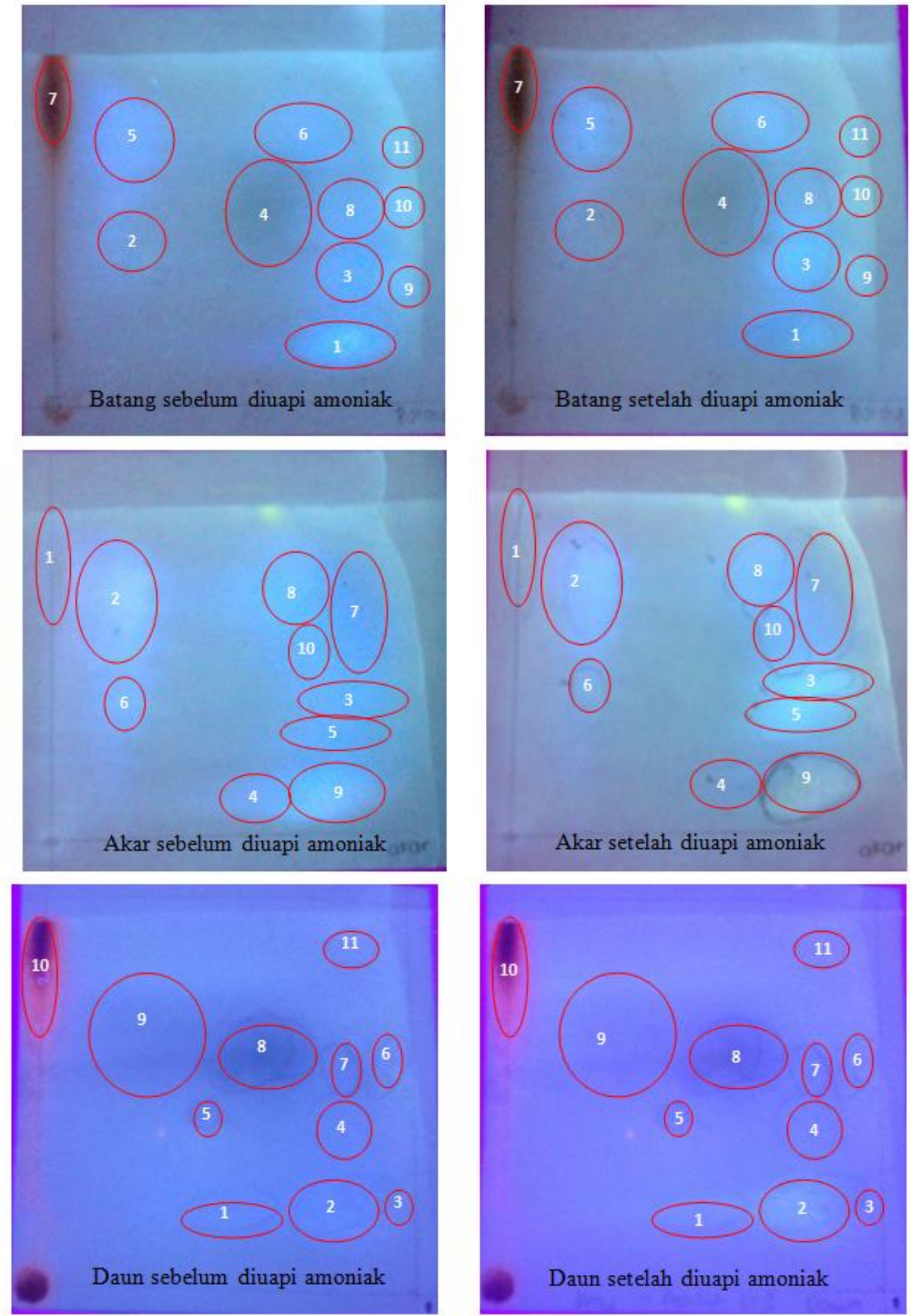

Gambar 5 Pola kromatogram dua arah meunggunakan eluen BAW dan asam asetat 15\%. 
Tabel 1. Data warna bercak dengan paparan sinar UV, nilai Rf, dan dugaan kelompok flavonoid dari hasil fraksinasi dengan kromatografi kertas

\begin{tabular}{cllcll}
\hline \multicolumn{2}{c}{ Batang } \\
\hline Bercak & Warna Tanpa NH3 & Warna Dengan NH3 & Nilai Rf & Dugaan & Referensi \\
\hline 1 & Fluoresensi biru & Fluorosensi biru & 17.2 & Isoflavon & {$[21],[25]$} \\
2 & Biru pudar & Biru pudar & 43.8 & Flavon/Flavonol & {$[21],[25]$} \\
3 & Fluorosensi biru & Fluorosensi biru & 37.5 & Isoflavon & {$[21],[25]$} \\
4 & Lembayung & Kuning & 54.7 & Flavon/Flavonol & {$[21],[25]$} \\
5 & Fluorosensi biru & Fluorosensi biru & 78.1 & Isoflavon/Flavanon & {$[21],[25]$} \\
6 & Fluorosensi biru & Fluorosensi biru & 78.1 & Flavon & {$[21],[25]$} \\
7 & Oranye & Oranye gelap & 84.4 & Antosianidin & {$[21],[25]$} \\
8 & Fluorosensi biru & Fluorosensi biru & 54.7 & Isoflavon & {$[21],[25]$} \\
9 & Fluorosensi biru-hijau & Biru-kekuningan & 35.9 & Flavonol & {$[21],[25]$} \\
10 & Fluorosensi biru-hijau & Biru-kekuningan & 57.0 & Flavonol & {$[21],[25]$} \\
11 & Fluorosensi biru-hijau & Biru-kekuningan & 75.0 & Flavonol & {$[21],[25]$} \\
\hline
\end{tabular}

\begin{tabular}{cllcll}
\hline \multicolumn{2}{c}{ Akar } \\
\hline Bercak & Warna Tanpa NH3 & Warna Dengan NH3 & Nilai Rf & Dugaan & Referensi \\
\hline 1 & Merah sindur & Merah sindur & 81.3 & Antosianidin & {$[21],[25]$} \\
2 & Fluoresensi biru-ungu & Fluoresensi biru-ungu & 70.7 & Flavon/Flavanon & {$[21],[25]$} \\
3 & Fluoresensi biru-pudar & Fluoresensi biru-pudar & 38.2 & Isoflavon & {$[21],[25]$} \\
4 & Biru pudar & Biru gelap & 13.0 & Flavon/Flavanon & {$[21],[25]$} \\
5 & Fluoresensi biru & Fluoresensi biru & 34.1 & Isoflavon & {$[21],[25]$} \\
6 & Fluoresensi biru & Fluoresensi biru & 49.4 & Flavon & {$[21],[25]$} \\
7 & Lembayung & Lembayung & 72.3 & Dihidroflavonol & {$[21],[25]$} \\
8 & Fluoresensi biru-ungu & Fluoresensi biru-ungu & 78.0 & Flavonol & {$[21],[25]$} \\
9 & Fluoresensi biru terang & Kuning kecoklatan & 14.6 & Flavon & {$[21],[25]$} \\
10 & Fluoresensi biru-ungu & Fluoresensi biru-ungu & 56.9 & Flavonol & {$[21],[25]$} \\
\hline
\end{tabular}

\begin{tabular}{cllcll}
\hline & & \multicolumn{3}{c}{ Daun } \\
\hline Bercak & Warna Tanpa NH3 & Warna Dengan NH3 & Nilai Rf & Dugaan & Referensi \\
\hline 1 & Fluoresensi biru & Fluoresensi biru terang & 21.1 & Flavon/Flavanon & {$[21],[25]$} \\
2 & Fluoresensi biru terang & Kuning & 23.9 & Flavon & {$[21],[25]$} \\
3 & Ungu & Ungu terang & 25.3 & Flavonol & {$[21],[25]$} \\
4 & Biru pudar & Biru pudar & 43.7 & Isoflavon/Khalkon & {$[21],[25]$} \\
5 & Ungu & Ungu & 46.5 & Flavon/Flavonol & {$[21],[25]$} \\
6 & Biru & Biru terang & 61.3 & Isoflavon & {$[21],[25]$} \\
7 & Biru & Biru terang & 59.8 & Isoflavon & {$[21],[25]$} \\
8 & Ungu tua & Ungu terang & 64.1 & Flavon/Flavonol & {$[21],[25]$} \\
9 & Ungu & Biru & 69.7 & Flavon/Flavonol & {$[21],[25]$} \\
10 & Merah sindur & Merah sindur & 84.5 & Antosianidin & {$[21],[25]$} \\
11 & Fluoresensi biru & Biru & 93.7 & Dihidroflavonol & {$[21],[25]$} \\
\hline
\end{tabular}

Secara umum ketiga jenis organ tanaman antinganting, memiliki beragam senyawa flavonoid. Namun, distribusi dan kandungannya berbeda antar tiap organ. Senyawa yang berpotensi sebagai senyawa antioksidan adalah flavonoid dari kelompok flavon dan flavonol, sedangkan isoflavon berpotensi sebagai senyawa antimikroba [19],[28]. Karena keberadaan senyawa ini, anting-anting dapat berpotensi sebagai sumber antioksidan dan antimikroba. Dari sisi penyiapan material tanaman, daun merupakan organ yang paling mudah diproses dibandingkan akar dan batang. Karena organ daun memiliki kandungan flavon, flavonol, khalkon, dan isoflavon, maka isolasi senyawa potensial dapat difokuskan pada organ daun.

\section{Pola Serapan Gelombang Cahaya Maksimum}

Setiap senyawa memiliki pola serapan cahaya yang khas sesuai dengan struktur molekulnya dan ikatannya dengan gugus lain, termasuk senyawa golongan flavonoid. Dari hasil dugaan awal kelas flavonoid (Tabel 1), kemudian dilakukan sampling pada beberapa bercak yang potensial untuk dilakukan pengukuran nilai absorbansi maksimum 
agar diperoleh pola serapan maksimum. Scanning dilakukan pada 12 dari 32 bercak dengan kisaran panjang gelombang $190 \mathrm{~nm}-400 \mathrm{~nm}$. Namun hanya dua sampel yang menunjukkan puncak serapan pada kisaran senyawa flavonoid, yaitu sampel daun no 2 (D2) dan daun no 4 (D4). Sampel-sampel lain juga menunjukkan puncak serapan, namun pada panjang gelombang dibawah $220 \mathrm{~nm}$. Puncak serapan dibawah $220 \mathrm{~nm}$ merupakan puncak serapan dari pelarut dalam spektrofotometri, bukan puncak serapan pada bahan bioaktif tertentu [29]. Pola serapan pada sampel D2 dan D4 disajikan pada Gambar 7.
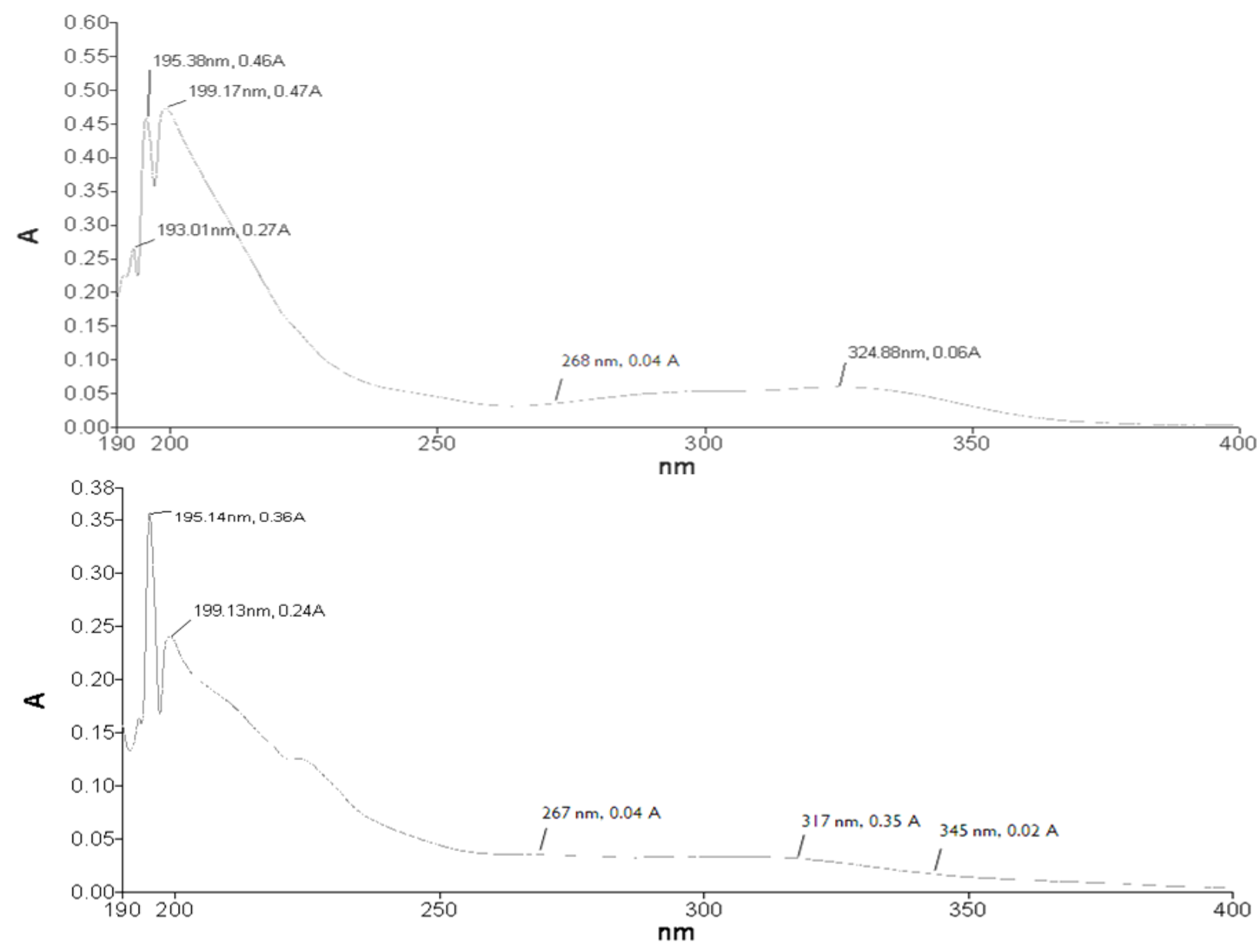

Gambar 7 Pola serapan panjang gelombang sampel D2 dengan puncak serapan pada 268 dan 324 nm (atas) serta sampel D4 dengan puncak serapan pada 267, 317, dan $345 \mathrm{~nm}$ (bawah).

Berdasarkan warna, letak, dan nilai Rf bercak telah diperoleh pengkelasan flavonoid (Tabel 1). Kebenaran dugaan pengkelasan flavonoid pada Tabel 1 dikonfirmasi dengan pola serapan maksimum hasil spektrofotometri. Sampel D2 tergolong ke dalam kelas flavon, dengan puncak serapan pada 268 dan $324 \mathrm{~nm}$. Berdasarkan panduan dalam [21], senyawa yang terkandung dalam bercak D2 diduga merupakan senyawa acacetin (4-metoksi apigenin). Acacetin merupakan senyawa kelas flavon yang memiliki antivitas antimikroba [28] dan berpotensi sebagai anti HIV [30].
Sampel D4 yang diduga masuk ke kelas isoflavon/khalkon. Setelah dilakukan konfirmasi menggunakan spektrofotometri, bercak tersebut lebih mendekati pada kelas khalkon dibanding isoflavon karena serapan maksimumnya berada pada 267, 317, dan $345 \mathrm{~nm}$. Berdasarkan panduan [21], senyawa yang terkandung dalam bercak D4 diduga merupakan 2',4'-dihidroksi-khalkon. Penelitian [31] menyatakan bahwa 2',4'-dihidroksikhalkon memiliki aktivitas antikanker melalui penghambatan ekspresi gen survivin yang berakibat pada kematian sel kanker. Konfirmasi lebih lanjut apakah senyawa pada sampel D2 dan 
D4 berturut-turut merupakan acacetin dan 2',4'dihidroksi-khalkon, perlu dilakukan pengujian HPLC pada panjang gelombang maksimum menggunakan senyawa acacetin dan 2',4'dihidroksi-khalkon standar.

\section{KESIMPULAN DAN SARAN}

Ketiga organ utama tanaman anting-anting (akar, batang, dan daun) memiliki distribusi kandungan senyawa yang berbeda-beda namun dengan kelas yang hampir sama. Golongan flavonoid yang berhasil teridentifikasi dari ketiga organ antara lain isoflavon, flavon, flavonol, flavanon, dihidroksiflavonol, khalkon, dan antosianidin. Organ daun memiliki keragaman kelas flavonoid lebih banyak dibanding akar dan batang.

Penelitian selanjutnya perlu dilakukan untuk mengkonfirmasi dua senyawa dugaan dari kelompok flavon dan khalkon (senyawa acacetin dan 2',4'-dihidroksi-khalkon) menggunakan HPLC dengan senyawa acacetin dan 2',4'-dihidroksikhalkon standar. Jika ternyata merupakan senyawa yang dimaksud, perlu dilakukan isolasi dan pemurnian senyawa bioaktif tersebut. Senyawa murni yang diperoleh kemudian dapat diuji pada bakteri uji untuk penghambatan mikroba dan aktivitas antioksidasi sebelum diujikan sebagai pengawet alami.

\section{UCAPAN TERIMA KASIH}

LP2M Universitas Al Azhar Indonesia atas dana Riset Grant No 009/SPK/A-01/UAI/II/2013 yang telah membiayai penelitian ini dan Dr Irawan Sugoro serta Laboratorium Terpadu UIN Syarif Hidayatullah atas bantuan dalam analisis spektrofotometri UV-Vis.

\section{DAFTAR PUSTAKA}

[1] K. E. Damayanti, A. Hikmat, E.A.M. Zuhud, International Workshop "Linking Biodiversity and Computer Vision Technology to Enhance Sistainable Utilization of Indonesian Tropical Medicinal Plants Bogor August 11, 2011.

[2] B.I. Purnawan, Inventarisasi keragaman jenis tumbuhan di taman nasional Gunung Gede Pangrango [skripsi]. Departemen Konservasi Sumberdaya Hutan dan Ekowisata. Institut Pertanian Bogor. Bogor, 2006.
[3] E.K. Damayanti, Legality of national park and involvement of local people: case studies in Java, Indonesia and Kerala, India [disertasi]. Graduate School of Life and Environmental Sciences, University of Tsukuba, 2008.

[4] K. Ganapathiraman, T.P.R. Bharadwaj, K.K Purushothaman, A Pilot study of Kuppaimeni (Acalypha indica), J Res Ind Med Yoga Hom 14: 81-86, 1979.

[5] RDJ, Solomon, S. Kallidass, J. Vimalan, Isolation identification and study of antimicrobial property of a bioactive compound in an Indian medicinal plant Acalypha indica (Indian-nettle), World J Microbiol Biotechnol 21:1231-1236, 2005.

[6] N. Harahap, Aktivitas senyawa antibakteri akar tumbuhan anting-anting (Acalypha indica L.) [skripsi], Program Studi Biokimia, FMIPA Institut Pertanian Bogor, 2006.

[7] M. Jamilah, Penentuan nilai $\mathrm{LD}_{50}$ ekstrak air herba akar kucing (Acalypha indica Linn) dan pengaruhnya terhadap kadar asam urat dalam darah tikus putih jantan yang diinduksi kalium oksonat [skripsi], Departemen Farmasi, FMIPA Universitas Indonesia, 2008.

[8] R. Ocktarimi, Pengaruh ekstrak herba anting-anting (Acalypha australis L.) terhadap kadar glukosa darah mencit Balb/C induksi Streptozotocin [skripsi], Fakultas Kedokteran, Universitas Sebelas Maret, 2010.

[9] C.J. Ikewuchi, C.C. Ikewuchi, E.N. Onyeike, A.A. Uwakwe, Nutritional potential of the leaves of Acalypha wilkesiana 'Godseffiana' Muell Arg. J Appl Sci Environ Manage, 2010.

[10] V.T. Narwade, A.A. Waghmare, A.L. Vaidya, Detection of flavonoids from Acalypha indica L. J Ecobiotechnol 3(11):5-7, 2011.

[11] N. Noriko, D. Elfidasari, R.L. Puspitasari, S.A. Nurjannah, Potensi daun anting-anting sebagai anti bakteri Salmonella thypi. Laporan Hasil Riset LP2M UAI, 2012.

[12] G. Tjirosoepomo, Taksonomi Tumbuhan ObatObatan, Yogyakarta: UGM Press, 1994.

[13] [Globinmed] Global information Hub On Integrated Medicine. [online] http://www.globinmed.com/index.php?option=com content \&view=article\&id=79285:acalypha-indica$\underline{\text { linn\&catid=199\&Itemid=139 (Diakses } 1 \text { Februari }}$ 2013).

[14] A.G. Singh, A. Kumar, D.D. Tewari, An ethnobotanical survey of medicinal plants used in Terai forest of western Nepal. J Ethnobiol Ethnomed 8(19):1-14, 2012.

[15] G. Priya, K. Saravanan, C. Renuka, Medicinal plants with potential antifertility activity: a review of sixteen years of herbal medicine research (1994 2010), Int J Pharmtech Res 4(1): 481-194, 2012.

[16] M.A. Rahman, S. Bachar, M. Rahmatullah, Analgesic and antiinflammatory activity of methanolic extract of Acalypha indica Linn. Pak J Pharm Sci 23(3):256-258, 2010. 
[17] E.H. Purwaningsih, N. Ibrahim, H. Zain, A. Tedjo, Neuro-protection and neuro-therapy effect of Acalypha indica Linn. water extract ex-vivo on Mucsulus gastrocnemius frog. Makara Kes 12(2): 71-76, 2008.

[18] M. Govindarajan M, A. Jebanesan, D. Reetha, R. Amsath, T. Pushpanathan, K. Samidurai, Antibacterial activity of Acalypha indica L. Eur Rev Med Pharmacol Sci 12:299-302, 2008.

[19] L. Taiz, E. Zeiger, Plant Physiology $5^{\text {th }}$ Ed, 2008.

[20] F.B. Salisbury, C.W. Ross, Fisiologi Tumbuhan Jilid 2, Bandung: ITB, 1995.

[21] K.R. Markham, Cara mengidentifikasi Flavonoid, Bandung: ITB, 1988.

[22] P. Sumthong and Verpoorte, Division of Pharmacognosy, Section Metabolomics, Institute of Biology, Leiden University, 2007.

[23] A. Jazilah, Rosita I, Pambudi A. Keragaman dan kandungan antioksidan golongan flavonoid Selaginella di Wanawisata Cangkuang, Sukabumi [laporan studi lapangan], Departemen Biologi, FMIPA, Institut Pertanian Bogor, 2006.

[24] A.C. Dweck, Natural Preservatives. 2003.

[25] J.B. Harborne. Metode Fitokimia. Bandung: ITB, 1987.

[26] L.K. Darusman, Diktat Kimia Analitik, Bogor:
Jurusan Kimia, FMIPA IPB, 2002.

[27] A. Pambudi, I. Rosita, A. Jazilah, S.A. Faulina. Analisis Kandungan Senyawa Golongan Flavonoid Selaginella yang Berpotensi sebagai Antioksidan. PKM Penulisan Ilmiah IPB, 2007.

[28] Y. Diab, K. Atalla, K. Elbanna, Antimicrobial screening of some Egyptian plants and active flavones from Lagerstroemia indica leaves. Drug Discover Therapeutic 6(4):212-217, 2012.

[29] S. Hess, Alvarez JL, Ittura G, Romero M. Evidence of UVB differential response in Sophora microphylla from shady and sunny places. Bol Soc Chil Quim, 2002. [online] http://www.scielo.cl/scielo.php?script=sci_arttext\& pid=S0366-16442002000400022 [Accessed 25 Agustus 2013].

[30] R.P. Samy, Gopalakhrisnakone, Therapeutic potential of plants as antimicrobials for drugs discovery. Adv Acc Publ eCAM 7(3): 283-294, 2010.

[31] C. Lou, G. Yang, H. Cai, M. Zou, Z. Xu, Y. Li, F. Zhao, W. Li, L. Tong, M. Wang, B. Cai, 2',4'Dihydroxychalcone-induced apoptosis of human gastric cancer MGC-803 cells via down-regulation of survivin mRNA. Toxicol in vitro 24: 1333-1337, 2010 . 